\title{
Molybdenum(VI) removal from aqueous solutions using bentonite and powdered cockle shell; Optimization by response surface methodology
}

\author{
Mojiri A. ${ }^{1,}$, Ahmad Z. ${ }^{1}$, Tajuddin R.M. ${ }^{2}$, Arshad M.F. ${ }^{1}$ and Barrera V. ${ }^{3}$ \\ ${ }^{1}$ Institute for Infrastructure Engineering and Sustainable Management (IIESM), Universiti Teknologi Mara (UiTM), Shah Alam 40450, \\ Selangor Darul Ehsan, Malaysia \\ ${ }^{2}$ Faculty of Civil Engineering, Universiti Teknologi Mara (UiTM), Shah Alam 40450, Selangor Darul Ehsan, Malaysia \\ ${ }^{3}$ Department of Chemical and Environmental Engineering, Federico Santa María Technical University, Valparaíso, Chile \\ Received: 23/03/2016, Accepted: 05/06/2017, Available online: 27/09/2017 \\ *to whom all correspondence should be addressed: \\ e-mail: amin.mojiri@gmail.com
}

\begin{abstract}
Removal of $\mathrm{Mo}(\mathrm{VI})$ from aqueous solutions by using bentonite and powdered cockle shell was conducted in this research. First, the effects of $\mathrm{pH}$ and initial $\mathrm{Mo}(\mathrm{VI})$ concentration on the Mo removal efficiency via shell and bentonite were studied. Results showed that Mo removal effectiveness increased as $\mathrm{pH}$ increased until 3.5. Removal efficiency of Mo via bentonite and shell also increased as initial $\mathrm{Mo}(\mathrm{VI})$ concentration increased to 30 or $40 \mathrm{mg} / \mathrm{L}$, respectively, after which the removal efficiency decreased. Response surface methodology and central composite design were applied to optimize removal effectiveness. Initial concentration of $\mathrm{Mo}(\mathrm{VI})(\mathrm{mg} / \mathrm{L}), \mathrm{pH}$, and shaking time (min) were selected as independent factors. These results showed that bentonite is more effective in removing Mo from water than the shell. At the optimum condition of 5.8 $\mathrm{pH}$, initial Mo concentration of $39.2 \mathrm{mg} / \mathrm{L}$, and shaking time of $38.6 \mathrm{~min}$, bentonite could remove $81.3 \%$ of Mo.
\end{abstract}

Keywords: Bentonite, Molybdenum(VI), Cockle Shell, RSM

\section{Introduction}

Non-stop release of industrial, urban, and agricultural wastes in rivers and lakes have resulted in the deposit of contaminants in environment. These contaminants include heavy metals that can endanger public health if incorporated in the food chain. Heavy metals are present in different types of industrial effluents and are responsible for environmental pollution (Barkhordar and Ghiasseddin, 2004). Incidence of heavy metal accumulation in fish, oysters, mussels, sediments, and other components of aquatic ecosystems has been reported (Kafshgari et al., 2013). Mo is one of the most vital of heavy metals. Mo is a transition metal from Group 6 of the periodic table, but its chemical properties are more similar to those of tungsten and vanadium from Group 5 than those of chromium from Group 6. A range of oxidation states is known for Mo, from
-2 to +6 , last one being the most common and stable oxidation state (de Castro Sousa, 2009).

Mo is considered a necessary trace element for both plants and animals. The conditionally recommended dietary intake of $\mathrm{Mo}$ is $75-250 \mu \mathrm{g} \cdot \mathrm{day}^{-1}$ for adults and older children (Lian et al., 2012; Moret and Rubio, 2003). Mo pollution has been reported in the past years. Given the large amounts of Mo-containing effluents from mine tailings without any pretreatment, such contamination has become a main water quality management issue in many regions of the world (Yu et al., 2011).

Mo is also applied in a variety of industrial procedures, for example, as an alloying agent in steels and cast iron, pigments for printing inks, paints and ceramics, solid lubricants, missile and aircraft paints, reactor vessels, die casting (copper base alloys), and in special batteries. However, Mo is toxic at high concentrations, and the maximum permissible limit in drinking water is $70 \mu \mathrm{g} \cdot \mathrm{L}^{-1}$ (Namasivayam and Sureshkumar, 2009).

Physical/chemical and biological methods can be used to remove metals from aqueous solutions. For example, some researchers have used electrochemical and electrocoagulation as a kind of physical/chemical method for metals removal (Vlachou et al., 2013; Liao et al., 2014; Kourdali et al., 2014; Gatsios et al., 2015). Some researchers use biological method such as activated sludge process for metals removal (Mojiri et al., 2016). But the majority of them is costly, time-consuming, and generates high amount of sludge (Moideen et al., 2015).

Among the many removal methods of metals, ion exchange and adsorption are the most effective and environmentally safe processes. Most ion exchangers are polymer matrices that immobilize various functional groups for metal ion uptake. Meanwhile, inorganic adsorbents are more commonly used due to both separation ability and physical properties such as resistance against heat and radioactivity (Nishihama and Yoshizuka, 2009). Several researchers 
(Yamada et al., 2001; Fujita et al., 2006; Anto and Annadurai, 2012; Ragheb, 2013) have used adsorption and ion-exchange methods to remove pollutants such as heavy metals.

Krika and Benlahbib (2015) demonstrated that adsorption process is an effective technique because of its efficiency, capacity, and applicability on large scale dye-removal, as well as the potential for regeneration, recovery, and recycling of adsorbents. Several materials have been used to remove metals from water and wastewater such as ash, activated carbon, zeolite, and limestone (Aziz, 2012; Ragheb, 2013; Mojiri et al., 2014). However, few studies have focused on improving the performance of cockle shell and bentonite for metal removal.

Bentonite clay is a 2:1 mineral formed into a layer with one octahedral sheet and two silica sheets. Bentonite carries a net negative charge due to the broken bonds around the edges of the silica-alumina units. This phenomenon results in unsatisfied charges, which could be balanced by exchanging cations (Bhattacharyya and Gupta, 2008). Therefore, the ion-exchange and/or adsorbent properties of bentonite clay have been investigated because of its framework (Sajidu et al., 2008). In the current study, cockle shell is another adsorbent which has also been used to adsorb metals. Cockle is a small and edible marine bivalve mollusk. Although many small edible bivalves are also called cockles, true cockles are species in the family Cardiidae (https://en.wikipedia.org/wiki/Cockle (bivalve). The shell of a cockle is rich in calcite that can be useful in ion-exchange and adsorption processes. Some researchers used cockle shell to remove pollutants from water (Kohler et al., 2008; Moideen et al., 2015)

This research aimed to (1) remove Mo(VI) from water using bentonite and powdered cockle shells, (2) optimize removal efficiency using response surface methodology (RSM), and (3) compare the performances of bentonite and cockle shell.

\section{Materials and Methods}

\subsection{Sampling Preparation}

This section had three parts. First, the effect of $\mathrm{pH}$ on removal efficiency of $\mathrm{Mo}(\mathrm{VI})$ was investigated at conditions of $30 \mathrm{mg} / \mathrm{L}$ initial Mo concentration, shaking time of $30 \mathrm{~min}$, and $2 \mathrm{~g} / \mathrm{L}$ adsorbent dosage. Second, the effect of initial Mo concentration on removal efficiency was determined at $\mathrm{pH}$ of 4, $30 \mathrm{~min}$ shaking time, and $2 \mathrm{~g} / \mathrm{L}$ adsorbent dosage. Finally, the Mo removal efficiency was optimized using $\mathrm{RSM}$, with $\mathrm{pH}$, initial $\mathrm{Mo}(\mathrm{VI})$ concentration, and shaking

Table 1. Characteristics of Bentonite and Oyster Shell time as independent factors. Based on preliminary experiments, the used adsorbent dosage was $2.5 \mathrm{~g} / \mathrm{L}$ for optimization process.

The standard solutions of $\mathrm{Mo}(\mathrm{VI})$ were prepared by dissolving analytical grade sodium molybdate $\left(\mathrm{Na}_{2} \mathrm{MoO}_{4} .2 \mathrm{H}_{2} \mathrm{O}\right)$ in deionized water in beakers with $200 \mathrm{~mL}$ working volume (Kafshgari et al., 2013). The $\mathrm{pH}$ of influent solutions was adjusted using a pH meter (YSI incorporated, USA) with $0.1 \mathrm{M} \mathrm{HCl}$ and/or $0.1 \mathrm{M} \mathrm{NaOH}$. Based on preliminary experiments, the samples were shaken at 200 rpm, which is in line with findings of Egute et al. (2011).

\subsection{Bentonite and Cockle Shell Characteristics}

The characteristics of bentonite and powdered cockle shells are shown in Table 1. In the current study, the sizes of powdered shell and bentonite ranged from $75 \mathrm{~mm}$ to $150 \mathrm{~mm}$ (Aziz et al., 2011). Based on XRD results (Fig. 1), $\mathrm{SiO}_{2} / \mathrm{Fe}_{2} \mathrm{O}_{3} / \mathrm{Al}_{2} \mathrm{O}_{3}$ and $\mathrm{CaCO}_{3}$ make up most of the bentonite, which is in line with findings of Naswir et al., (2013). Based on the FTIR results (Fig. 3), picks of 3400$3630,2300,1040,690-790$, and 460-600 could be O-H, O$\mathrm{H}, \mathrm{C}-\mathrm{O}, \mathrm{C}-\mathrm{H}$, and S-S or Si-Cl, respectively (Coates, 2000).

XRD results showed that $\mathrm{CaCO}_{3}$ makes up most of the cockle shell (Fig. 2), which adheres to the findings of Kamba et al. (2013). Based on the FTIR results (Fig. 4), picks of 700800, 1424-1797, 2513-2872, and 3200-3500 could belong to $\mathrm{C}-\mathrm{Cl}$, carboxylic acid or carbonate ion, $\mathrm{C}-\mathrm{H}$, and $\mathrm{Si}-\mathrm{O}-\mathrm{Si}$, respectively (Coates, 2000).

\subsection{Analytical Methods}

All experiments were carried out in accordance with the Standard Methods (APHA, 2005). The YSI Inc., USA was used to record the $\mathrm{pH}$ and temperature $\left({ }^{\circ} \mathrm{C}\right)$. Electrical conductivity (S/m) was monitored using SANXINMP515-03, and ICP (HITACHI, PS3500DD) was used to measure Mo concentrations.

\subsection{Statistical Analysis}

The Mo(VI) removal efficiencies were tested by identifying the target parameters before and after treatment. Removal efficiency was designed using the equation (Equation 1)

$$
\text { Removal }(\%)=\frac{(\mathrm{Ci}-\mathrm{Cf}) * 100}{\mathrm{Ci}}
$$

where $C i$ and $C f$ are the initial and final concentrations of the parameters, respectively.

\begin{tabular}{ccc}
\hline Parameters & Bentonite & Cockle Shell \\
\hline Surface Area $\left(\mathrm{m}^{2} / \mathrm{g}\right)$ & $23.48 \mathrm{ex}+1$ & $25.97 \mathrm{ex}+1$ \\
\hline External Surface Area $\left(\mathrm{m}^{2} / \mathrm{g}\right)$ & $22.13 \mathrm{ex}+1$ & $22.98 \mathrm{ex}+1$ \\
\hline Micropore Area $\left(\mathrm{m}^{2} / \mathrm{g}\right)$ & $5.27 \mathrm{ex}+1$ & $6.05 \mathrm{ex}+1$ \\
\hline Micropore Volume $(\mathrm{cc} / \mathrm{g})$ & $0.008 \mathrm{ex}+1$ & $0.010 \mathrm{ex}+1$
\end{tabular}

Thickness Method: DeBoer 


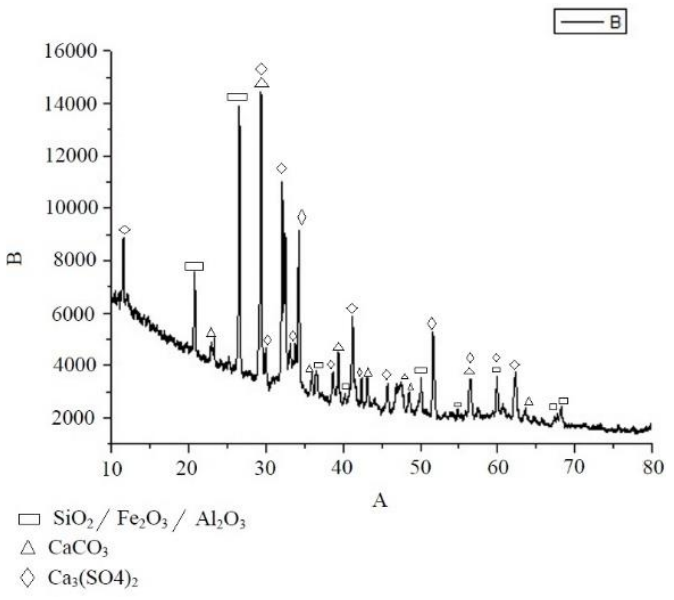

Figure 1. XRD Results of Bentonite

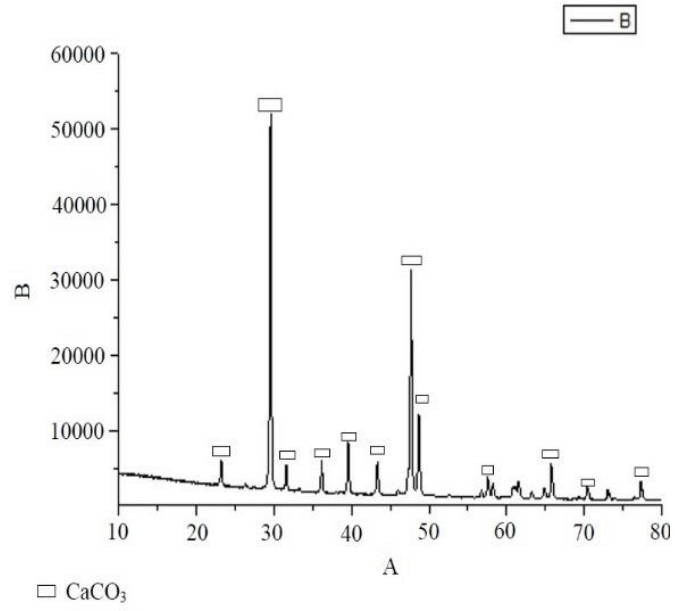

Figure 2. XRD Results of Cockle Shell

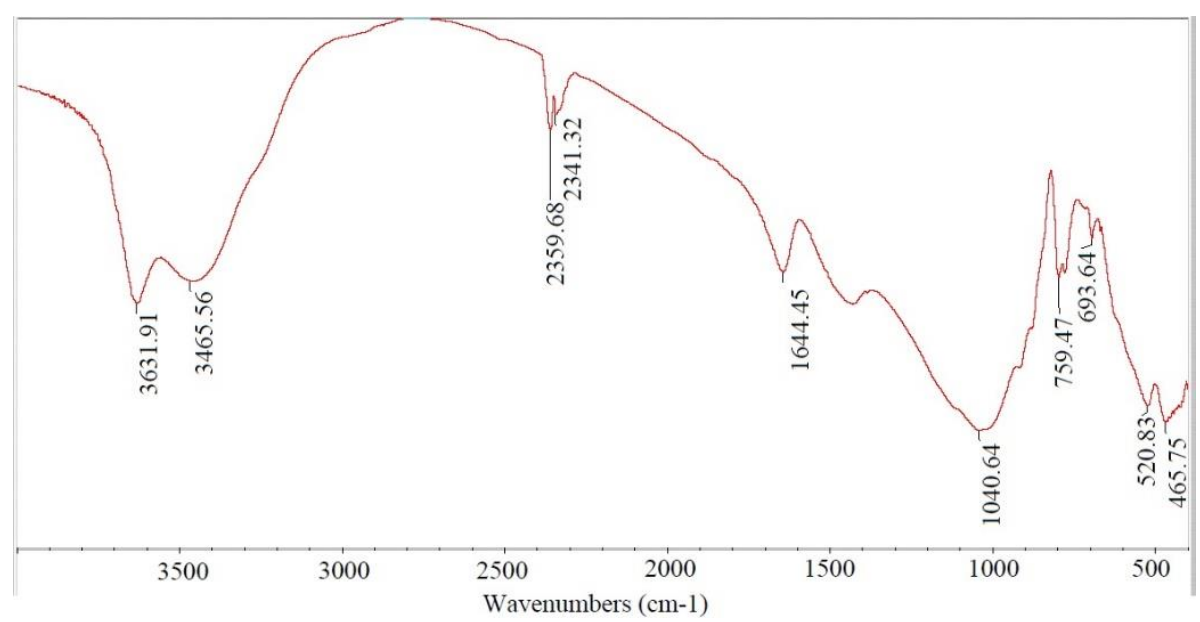

Figure 3. FTIR Results of Bentonite

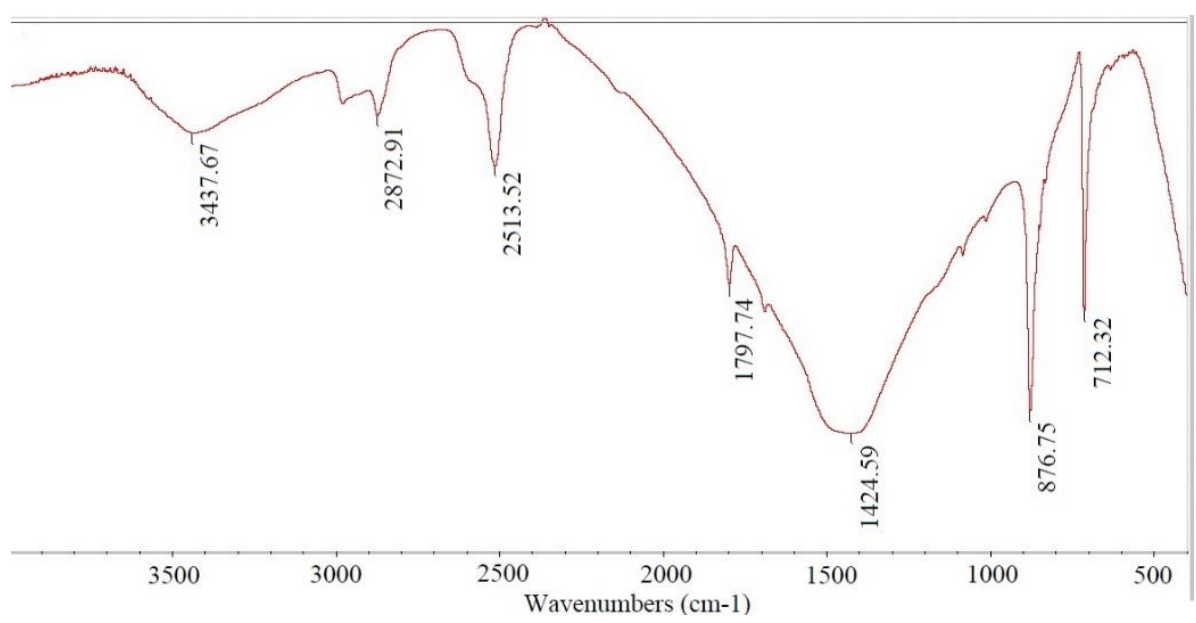

Figure 4. FTIR Results of Cockle Shell

Central composite design (CCD) and RSM were used to plan the experiments and data analysis. CCD was implemented with Design Expert Software Version 6.0.7. Equation 2, an empirical second-order polynomial model, accounts for the behavior of the system, which is expressed as

$$
\beta_{o}+\sum_{i=1}^{k} \beta_{i} \cdot X_{i}+\sum_{i=1}^{k} \beta_{i i} X_{i}^{2}+\sum_{i_{i}<j}^{k} \sum_{j}^{k} \beta_{i j} X_{i} X_{j}+\ldots+e
$$

where $Y$ represents the response, $X_{\mathrm{i}}$ and $X_{\mathrm{j}}$ represent the variables, $b_{0}$ represents a constant coefficient; $b_{\mathrm{j}}, \boldsymbol{b}_{\mathrm{jj}}$, and $\boldsymbol{B}_{\mathrm{ij}}$ represent the interaction coefficients of the linear, quadratic, and second-order terms, respectively; $k$ is the number of studied factors; and $e$ represents the error. 
ANOVA was used to fully analyze the results obtained using the Design Expert Software. The design included $k^{2}$ factorial points supported by $2 k$ axial points and a center point, where $k$ represents the number of variables (Mojiri et al., 2013). A number of researchers used RSM to optimize pollutant removal from leachates and wastewater (Mohajeri et al., 2010; Umar et al., 2011; Adlan et al., 2011). In the current research, $\mathrm{pH}$ (3-6), initial concentration of $\mathrm{Mo}(\mathrm{VI})(20-60 \mathrm{mg} / \mathrm{L})$, and shaking time (30-90 $\mathrm{min}$ ) have been selected as independent factors.

\subsection{Adsorption Isotherms}

If the adsorbent and adsorbate interact long enough, the equilibrium will set between the amount of adsorbate

Table 2. Experimental variables and results for Mo removal by bentonite

\begin{tabular}{ccccc}
\hline Run & pH & Concentration of Mo(VI), (mg/L) & Shaking Time, (min) & Removal, (\%) \\
\hline 1 & 4.50 & 40.00 & 40.00 & 79.49 \\
\hline 2 & 4.50 & 50.00 & 40.00 & 78.88 \\
\hline 3 & 4.50 & 40.00 & 40.00 & 78.92 \\
\hline 4 & 3.00 & 20.00 & 20.00 & 58.25 \\
\hline 5 & 4.50 & 40.00 & 40.00 & 79.13 \\
\hline 6 & 4.50 & 40.00 & 40.00 & 80.03 \\
\hline 7 & 3.00 & 20.00 & 60.00 & 58.27 \\
\hline 8 & 4.50 & 30.00 & 40.00 & 72.51 \\
\hline 9 & 6.00 & 60.00 & 60.00 & 48.45 \\
\hline 10 & 4.50 & 40.00 & 30.00 & 70.31 \\
\hline 11 & 4.50 & 40.00 & 50.00 & 73.56 \\
\hline 12 & 3.75 & 40.00 & 40.00 & 81.37 \\
\hline 13 & 4.50 & 40.00 & 40.00 & 78.89 \\
\hline 14 & 5.25 & 40.00 & 40.00 & 78.79 \\
\hline 15 & 3.00 & 60.00 & 60.00 & 56.98 \\
\hline 16 & 3.00 & 60.00 & 20.00 & 60.27 \\
\hline 17 & 6.00 & 20.00 & 20.00 & 52.03 \\
\hline 18 & 6.00 & 20.00 & 60.00 & 46.39 \\
\hline 19 & 6.00 & 60.00 & 20.00 & 47.67 \\
\hline 20 & 4.50 & 40.00 & 40.00 & 79.41 \\
\hline
\end{tabular}

Table 3. Experimental variables and results for Mo removal by shell

\begin{tabular}{ccccc}
\hline Run & pH & Concentration of Mo(VI), (mg/L) & Shaking Time, (min) & Removal, (\%) \\
\hline 1 & 4.50 & 40.00 & 60.00 & 59.83 \\
\hline 2 & 4.50 & 50.00 & 60.00 & 60.06 \\
\hline 3 & 4.50 & 40.00 & 60.00 & 60.16 \\
\hline 4 & 3.00 & 20.00 & 30.00 & 73.81 \\
\hline 5 & 4.50 & 40.00 & 60.00 & 59.59 \\
\hline 6 & 4.50 & 40.00 & 60.00 & 59.59 \\
\hline 7 & 3.00 & 20.00 & 90.00 & 63.91 \\
\hline 8 & 4.50 & 30.00 & 60.00 & 61.91 \\
\hline 9 & 6.00 & 60.00 & 90.00 & 45.32 \\
\hline 10 & 4.50 & 40.00 & 45.00 & 61.00 \\
\hline 11 & 4.50 & 40.00 & 75.00 & 58.17 \\
\hline 12 & 3.75 & 40.00 & 60.00 & 65.76 \\
\hline 13 & 4.50 & 40.00 & 60.00 & 58.71 \\
\hline 14 & 5.25 & 40.00 & 60.00 & 49.34 \\
\hline 15 & 3.00 & 60.00 & 90.00 & 60.17 \\
\hline 16 & 3.00 & 60.00 & 30.00 & 61.29 \\
\hline 17 & 6.00 & 20.00 & 30.00 & 44.39 \\
\hline 19 & 6.00 & 20.00 & 90.00 & 44.62 \\
\hline 20 & 4.50 & 60.00 & 30.00 & 44.13 \\
\hline
\end{tabular}


Langmuir and Freundlich isotherms were used in this study to display the characteristics of bentonite and shell adsorptions.

In the present investigation for adsorption isotherm testing, $30 \mathrm{mg} / \mathrm{L}$ of Mo was added in $200 \mathrm{~mL}$ beakers containing different ratios of adsorbents between 0-2.5 $\mathrm{g} / \mathrm{L}$. Beakers were shaken for $30 \mathrm{~min}$ at $200 \mathrm{rpm}$. And the $\mathrm{pH}$ has been fixed on 4

\section{Results and Discussion}

This study treated $\mathrm{Mo}(\mathrm{VI})$-polluted water using adsorbents. Tables 2 and 3 show the experimental variables and results of Mo removal by bentonite and shell based on RSM design. This study follows up two main points, namely, the effects of $\mathrm{pH}$ and initial concentration of Mo on Mo removal by bentonite and shell and the optimization of Mo removal using RSM

\subsection{Effects of $\mathrm{pH}$ on Molybdenum Removal}

With the use of bentonite, the removal efficiency of $\mathrm{Mo}(\mathrm{VI})$ varied from $62.2 \%(\mathrm{pH}=6)$ to $71.14 \%(\mathrm{pH}=3.5)$ (Fig. 5). Mo removal decreased with increasing $\mathrm{pH}$, where maximum removal was stable at $\mathrm{pH} 3.5$ and decreased after exceeding $\mathrm{pH} 4.5$. This result coincides with the findings of Rabelo et al. (2007).

Using cockle shell, the removal efficiency of $\mathrm{Mo}(\mathrm{VI})$ varied from $45.8 \%(\mathrm{pH}=6)$ to $65.1 \%(\mathrm{pH}=3.5)$ (Fig. 5). Mo removal decreased with increasing $\mathrm{pH}$, where the maximum removal was stable at $\mathrm{pH}$ 3.5. This observation agrees with the findings of Pagnanelli et al. (2011) and Meena et al. (2010).

The $\mathrm{pH}$ of the solution is a vital factor in adsorption processes (Mehdizadeh et al., 2014). Usually, more metals are adsorbed at lower $\mathrm{pH}$. In literatures, mostly researchers have used acidic $\mathrm{pH}$ to neutral $\mathrm{pH}$ in removing metals with adsorption methods because metals are more extractable and harmful in acidic pHs (Olaniran et al., 2013). The heavy metals are completely released under extreme acidic conditions (Annadurai et al., 2003). However, in extremely low $\mathrm{pH}(>3)$, metal removal declines because $\mathrm{H}^{+}$ions compete with metal cations for the adsorption sites in the system (Abdel-Ghani et al., 2007).

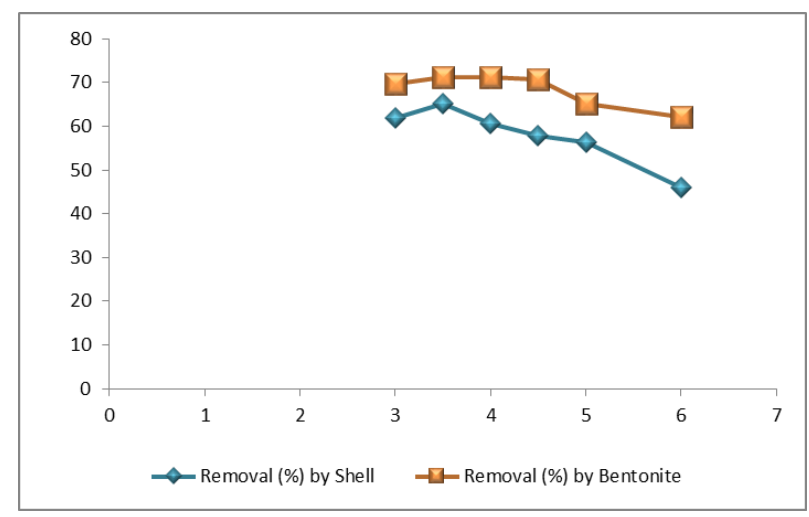

Figure 5. Effects of pH on Removal Efficiency

\subsection{Effects of Initial Concentration}

In removal using bentonite, the removal efficiency of $\mathrm{Mo}(\mathrm{VI})$ varied from $60.7 \%$ (initial concentration=60 $\mathrm{mg} / \mathrm{L}$ ) to $69.88 \%$ (initial concentration $=40 \mathrm{mg} / \mathrm{L}$ ) (Fig. 6). Mo removal increased along with the initial concentration until $40 \mathrm{mg} / \mathrm{L}$ was reached, where maximum removal was stable at $40 \mathrm{mg} / \mathrm{L}$ to $50 \mathrm{mg} / \mathrm{L}$ and decreased afterward.

In removal using cockle shell, the removal efficiency of $\mathrm{Mo}(\mathrm{VI})$ varied from $48.1 \%$ (initial concentration=60 $\mathrm{mg} / \mathrm{L}$ ) to $63.0 \%$ (initial concentration $=30 \mathrm{mg} / \mathrm{L}$ ) (Fig. 6). Mo removal efficiency increased as initial concentration increased up to $30 \mathrm{mg} / \mathrm{L}$, after which the removal efficiency declined.

This can be clarified that each adsorbent has a fixed number of active adsorption sites, which are accessible to adsorb more metal ions at lower concentrations, but as the concentration increases, the active sites becomes saturated leading to a reduction in the percentage removal. On the other hand, an increase in the uptake capacity for metal ions with increase in initial metal ion concentration was obtained. This sorption characteristic indicated that surface saturation is a function of the initial metal ion concentration in solution (Akpomie and Dawodu, 2015).

At high concentrations, there are more heavy metal ions than available adsorption sites. Hence, the percent removal of heavy metals depends on the initial metal ion concentration; percent removal decreases as initial metal ion concentration increases (Meena et al., 2005).

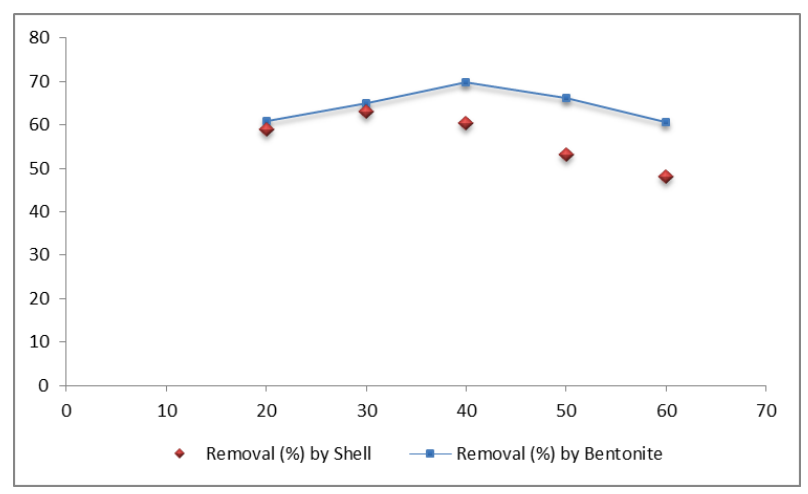

Figure 6. Effects of Initial Concentration of Molybdenum(VI) on Removal Efficiency

\subsection{Optimization Process}

Tables 4 and 5 show the ANOVA results for response parameters and the value of response at optimum conditions, respectively. Also the $3 D$ surface plots of molybdenum(VI) removal by bentonite and shell are shown in Figure 7. The removal percentage of Mo by shell was highest at $\mathrm{pH} 3.3$, initial $\mathrm{Mo}(\mathrm{VI})$ concentration of $20.0 \mathrm{mg} / \mathrm{L}$, and shaking time of $30.0 \mathrm{~min}$. However, the removal percentage of Mo was greatest at $\mathrm{pH} 5.8$, initial Mo(VI) concentration of 39.2, and shaking time of 38.6, showing that bentonite is more efficient than the powdered shell in removing Mo(VI). Mojiri (2011) stated that ion-exchange is the most important way to remove metals. Bentonite is clay which can facilitate ion-exchange because of its 
aluminosilicate structure. Adsorption process of metal ions into pores of clays occurred quickly at the first moments. The ion exchange could be a further process for elimination of metals onto bentonite (Galindo et al., 2013). Also bentonite, as clay, has a reasonable cation exchange capacity (CEC) which shows clays can play a strong role in removing metals. Beside these reasons, bentonite surface area is more than the cockle shell surface area based on table 1 . So these reasons show why bentonite performance in removing metals is more than cockle shell performance.
In addition, the optimum shaking time set to remove Mo using shell and bentonite was 30 and $39 \mathrm{~min}$. Meena et al. (2005) stated that the contact time required to attain equilibrium is dependent on the initial concentration of heavy metals. For the same concentration, the percentage removal of heavy metal increases with increase of contact time until equilibrium is attained.

Table 4. ANOVA results for response parameters

\begin{tabular}{|c|c|c|c|c|c|c|c|c|}
\hline Adsorbent & Final equation in terms of actual factor & Prob. & $\mathbf{R}^{2}$ & Adj. $\mathbf{R}^{2}$ & SD & CV & PRESS & Prob. LOF \\
\hline Bentonite & $\begin{array}{c}33.020-35.648 \mathrm{~A}+1.873 \mathrm{~B}+4.806 \mathrm{C}+3.693 \mathrm{~A}^{2}- \\
0.023 \mathrm{~B}^{2}-0.060 \mathrm{C}^{2}-0.012 \mathrm{AB}-0.006 \mathrm{AC}+ \\
0.0009 \mathrm{BC}\end{array}$ & 0.0001 & 0.9842 & 0.9700 & 2.22 & 3.27 & 737.04 & 0.6312 \\
\hline Shell & $\begin{array}{c}60.455+23.753 \mathrm{~A}-1.502 \mathrm{~B}-0.179 \mathrm{C}-3.953 \mathrm{~A}^{2}+ \\
0.012 \mathrm{~B}^{2}-0.0008 \mathrm{C}^{2}+0.069 \mathrm{AB}+0.034 \mathrm{AC}+ \\
0.02 \mathrm{BC}\end{array}$ & 0.0001 & 0.9733 & 0.9493 & 1.78 & 3.10 & 472.05 & 0.0822 \\
\hline
\end{tabular}

Notes: Prob: Probability of error; $R^{2}$ : Coefficient of determination; Adj. $R^{2}$ : Adjusted R2; Adec. P: Adequate precision; SD: Standard deviation; CV: Coefficient of variance; PRESS: Predicted residual error sum of square; Prob. LOF: Probability of lack of fit.

In final equations, where $\mathrm{A}$ is $\mathrm{pH}$; $\mathrm{B}$ is initial concentration of $\mathrm{Mo}(\mathrm{mg} / \mathrm{L})$, and $\mathrm{C}$ is shaking time $(\mathrm{min})$.

Table 5. The value of response at optimum conditions

\begin{tabular}{|c|c|c|c|c|}
\hline \multirow{2}{*}{ Adsorbent } & \multicolumn{3}{|c|}{ Independent Factors } & Responses \\
\cline { 2 - 5 } & A & B & C & Mo(VI) rem., (\%) \\
\hline Bentonite & 5.89 & 39.27 & 38.62 & 73.69 \\
\hline Cockle Shell & 3.31 & 20.00 & 30.00 & 73.69 \\
\hline
\end{tabular}

(A): $\mathrm{pH}$; (B) Initial Concentration of $\mathrm{Mo}(\mathrm{mg} / \mathrm{L})$; (C): Shaking Time (min)
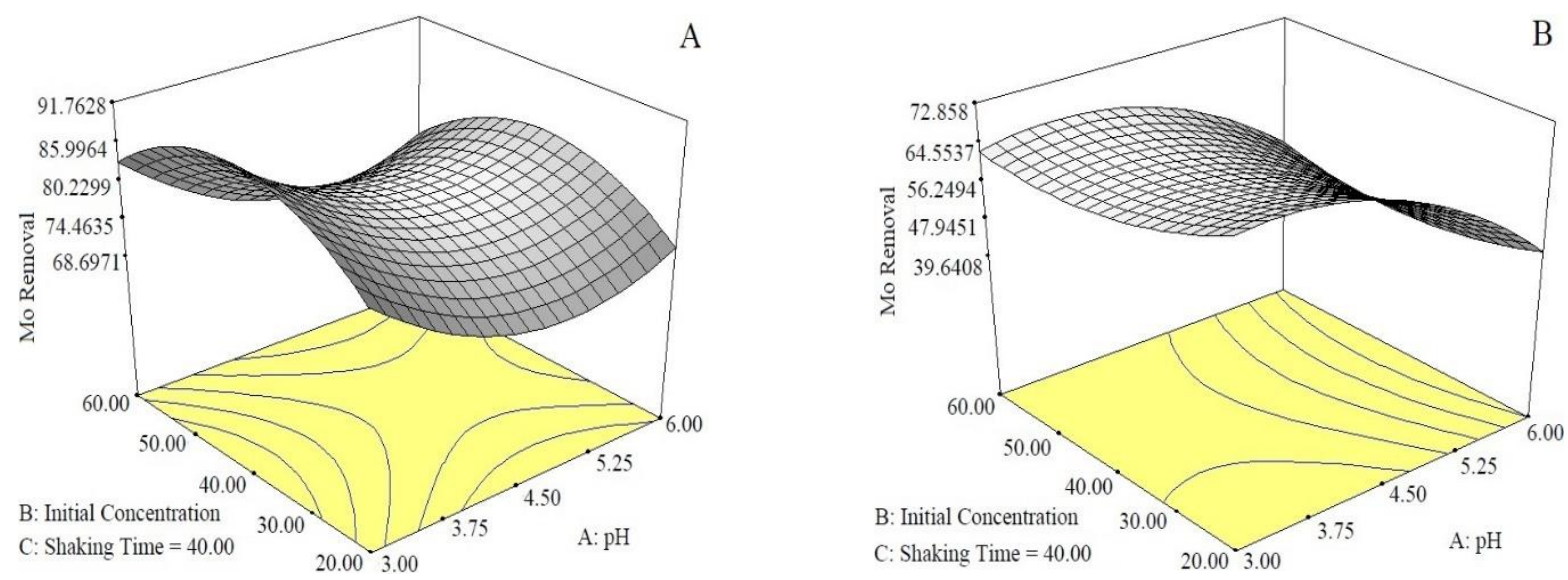

Figure 7. The 3D Surface Plots of Molybdenum(VI) Removal by (A) Bentonite, and (B) Shell

\subsection{Langmuir Isotherm}

Langmuir quantitatively demonstrates the formation of a monolayer adsorbate on the outer surface of the adsorbent. Thus, Langmuir displays the equilibrium distribution of ions between the solid and liquid phases (Dada et al., 2012). The Langmuir isotherm is valid for monolayer adsorption onto a surface containing a finite number of identical sites. Langmuir equation can be summarized as (Altig, 2013).

$$
\frac{x}{m}=\frac{a b c_{e}}{\left(1+b c_{e}\right)}
$$

where $\mathrm{x} / \mathrm{m}$ is the mass of the adsorbate adsorbed per unit mass of adsorbent ( $\mathrm{mg}$ adsorbate per $\mathrm{g}$ activated carbon), $a$ and $b$ are the empirical constants, and $C_{\mathrm{e}}$ is the equilibrium concentration of adsorbate in the solution after adsorption ( $\mathrm{mg} / \mathrm{L})$.

The adsorption capacities (Q) of Mo using bentonite and shell were $0.981 \mathrm{mg} / \mathrm{g}$, and $0.975 \mathrm{mg} / \mathrm{g}$, respectively (Table 6; Fig. 8-9). Mojiri et al. (2016) reported $Q=0.70 \mathrm{mg} / \mathrm{g}$ for adsorption of Fe by composite adsorbent. The energy of adsorption values (b) for removal by bentonite and shell were -8.671 and $-6.519 \mathrm{~L} / \mathrm{mg}$, respectively. The negative values indicated that the increase in $C_{e}$ caused a decrease in $\mathrm{x} / \mathrm{m}$ (Aziz et al., 2012). The $R^{2}$ values (goodness fit criterion) for both isotherms were calculated using linear regression, and $R^{2}$ of removal by bentonite and shell were 0.9847 and 0.980 , respectively. These results show that the Langmuir isotherm can be used to explain the adsorption by bentonite and shell. 
The same $R^{2}$ values were reported by Dodbiba et al. (2010) regarding $\mathrm{Mo}$ adsorption by $\mathrm{Pb}-\mathrm{Fe}$-based adsorbents. $\mathrm{A}$ dimensionless equilibrium parameter separation factor $(\mathrm{RL})$ could be used to express the characteristics of the

\begin{tabular}{cccccc}
\hline Adsorbent & $\mathbf{Q}_{0},(\mathbf{m g} / \mathbf{g})$ & $\mathbf{b}$ & $\mathbf{R}^{\mathbf{2}}$ & $\mathbf{R}_{\mathbf{L}}=\frac{\mathbf{1}}{\mathbf{1 + b C _ { \mathbf { 0 } }}}$ & Isotherm type* \\
\hline Bentonite & 0.981 & -8.671 & 0.9847 & -0.003 & unfavorable \\
\hline Shell & 0.975 & -6.519 & 0.980 & -0.005 & unfavorable \\
\hline
\end{tabular}

*Note: $0<\mathrm{RL}<1$ = favorable; $\mathrm{R}<1$ = unfavorable
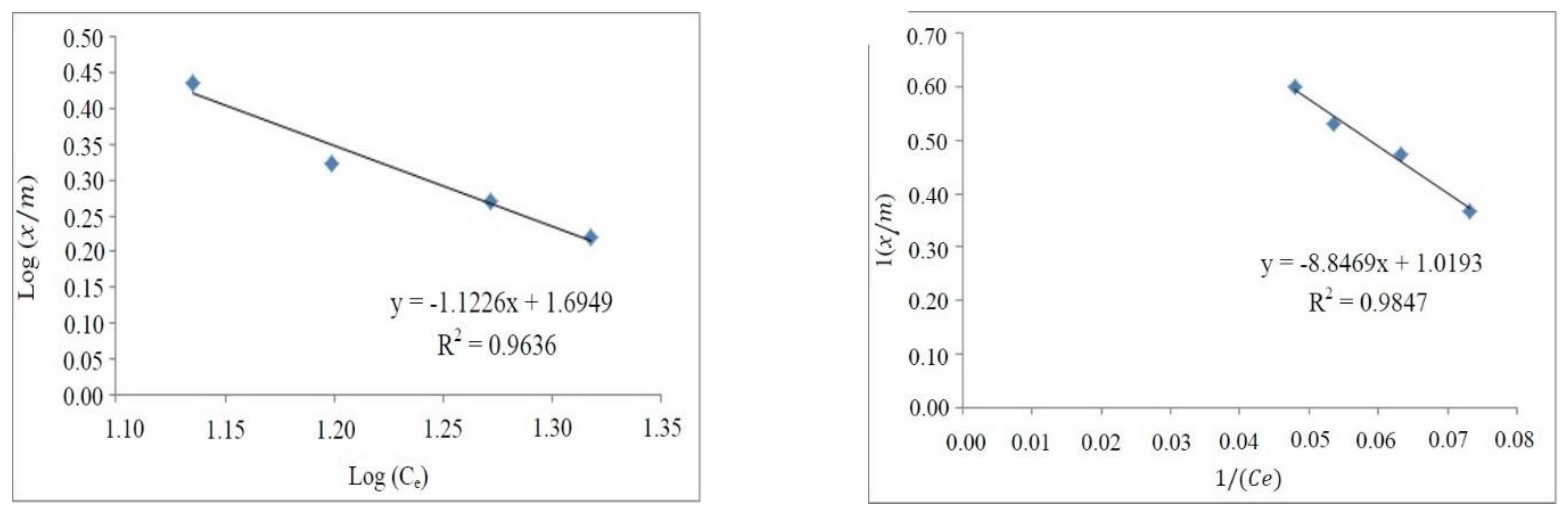

Figure 8. Freundlich and Langmuir Isotherms Regression for Removal by Bentonite

\subsection{Freundlich isotherm}

The Freundlich isotherm is commonly used to describe the adsorption characteristics for heterogeneous surfaces (Dada et al., 2012). The Freundlich equation can be written as

$$
\frac{x}{m}=K_{f} C_{e}^{1 / n}
$$

Langmuir isotherm (Isa et al., 2007). The RL values for $\mathrm{Mo}(\mathrm{VI})$ adsorption by bentonite and shell were -0.003 and -0.005 , respectively.

Table 6. Langmuir equation for Mo(VI) removal by bentonite and shell

where $K_{\mathrm{f}}$ is a constant indicative of the relative adsorption capacity of the adsorbent $\left(\mathrm{mg}^{1-(1 / n)} \mathrm{L}^{1 / n} \mathrm{~g}^{-1}\right)$ and $n$ is a constant that refers to the intensity of the adsorption (Hamdaoui and Naffrechoux, 2007).

The obtained Freundlich capacity factors (K) for Mo(VI) removal by bentonite and shell were 49.57 and 22.72

Table 7. Freundlich equation for $\mathrm{Mo}(\mathrm{VI})$ removal by bentonite and shell (mg/g) (L/mg) $1 / \mathrm{n}$, respectively (Table 7, Figs. 8-9). Namasivayam and Sureshkumar (2009) reported $K_{\mathrm{f}}$ values of $17.1 \mathrm{mg} / \mathrm{g}$. Higher $\mathrm{K}$ values showed greater capacities of adsorption (Aziz et al., 2004). The obtained $1 / n$ values for Mo (VI) removal by bentonite and shell were -1.12 ( $n=-$ 0.89 ) and $0.323(n=-1.19)$, respectively. The $1 / n$ (slope of the line) was negative because increasing the $\log \left(C_{e}\right)$ caused the decrease of $\log (\mathrm{x} / \mathrm{m}) . R^{2}$ values for Mo removal by bentonite and shell were 0.9636 and 0.9286 , respectively. These observations show that the adsorption of Mo by bentonite and shell could be well explained by the Freundlich isotherm. The same $R^{2}$ values have been reported by Lian et al. (2012).

\begin{tabular}{ccccc}
\hline Adsorbent & $\mathbf{K}_{\mathrm{f}}\left(\mathbf{m g} / \mathbf{g}(\mathbf{L} / \mathbf{m g})^{\mathbf{1 / n}}\right)$ & $\mathbf{1} / \mathbf{n}$ & $\mathbf{n}$ & $\mathbf{R}^{\mathbf{2}}$ \\
\hline Bentonite & 49.578 & -1.122 & -0.890 & 0.9636 \\
\hline Cockle Shell & 22.727 & -0.833 & -1.199 & 0.9286 \\
\hline
\end{tabular}
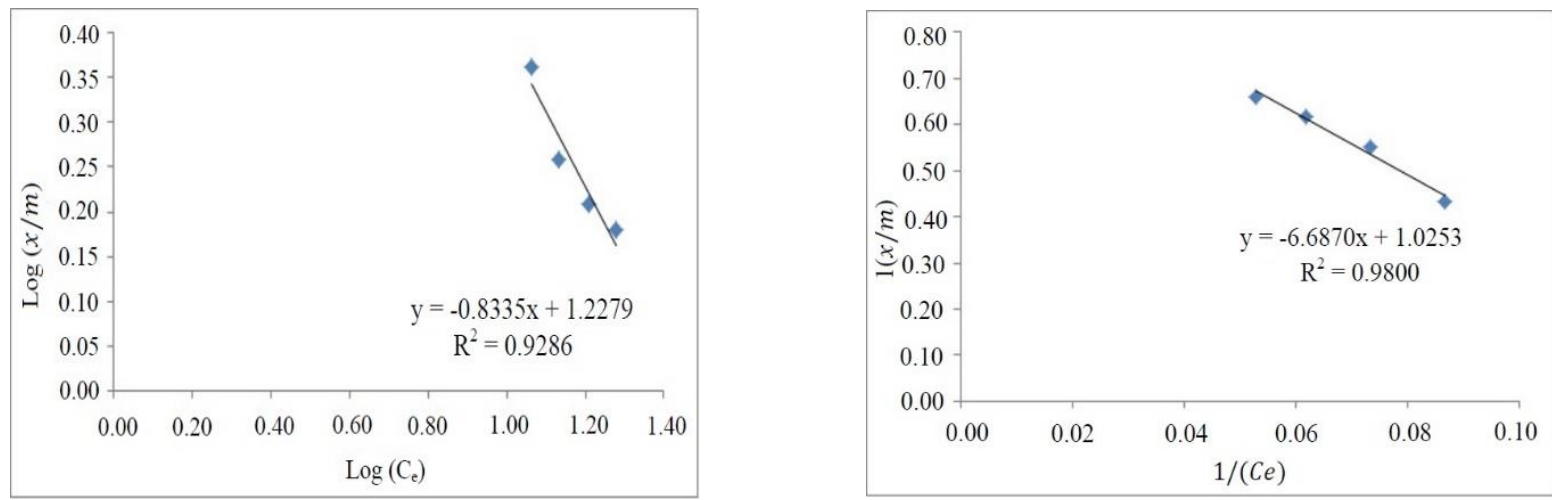

Figure 9. Freundlich and Langmuir Isotherms Regression for Removal by Shell 


\section{Conclusions}

Environmental pollution has rapidly increased because of urbanization and industrialization. Several pollutants such as heavy metals accumulate in water and soil. Mo is a heavy metal and a toxic pollutant. The effects of $\mathrm{pH}$ and initial $\mathrm{Mo}(\mathrm{VI})$ concentration on removal of Mo using bentonite and cockle shell were investigated, and CCD and RSM were used to optimize removal efficiency. The main conclusions of this study are presented below.

(1) $\mathrm{Mo}(\mathrm{VI})$ removal increased as $\mathrm{pH}$ increased until 3.5.

(2) Removal efficiency increased as initial concentration increased. When initial concentrations exceeded 30-40 $\mathrm{mg} / \mathrm{L}$ during shell and bentonite treatments, the removal efficiency decreased.

(3) Compared with the shell, bentonite was more efficient in removing Mo from water. Bentonite could remove $81.3 \%$ of Mo and shell could remove $73.6 \%$ of Mo from water.

(4) Adsorption of $\mathrm{Mo}(\mathrm{VI})$ by bentonite and shell could be explained based on the resulting $R^{2}$ values of the Langmuir and Freundlich isotherms.

\section{Acknowledgment}

The authors would like to express their gratitude to the Institute for Infrastructure Engineering and Sustainability Management (IIESM), Universiti Teknologi Mara (UiTM) for their supports.

\section{References}

Abdel-Ghani N.T., Hefny, M. and El-Chaghaby G.A.F. (2007), Removal of lead from aqueous solution using low cost abundantly available adsorbents, Inter. J. Environ. Sci. and Technol., 4(1), 67-73.

Adlan M.N., Palaniandy P. and Aziz H.A. (2011), Optimization of coagulation and dissolved air flotation (DAF) treatment of semi-aerobic landfill leachate using response surface methodology (RSM), Desalination, 277(1-3), 74-82.

Akpomie K.G. and Dawodu F.A. (2015), Potential of a low-cost bentonite for heavy metal abstraction from binary component system, Beni-Suef University Journal of Basic and Applied Sciences, 4(1), 1-13.

Altig J. (2013). The Langmuir Adsorption Isotherm. Physical Chemistry Laboratory, Revision 2.0, pp. 1-7, CHEM 331L, Available at: http://infohost.nmt.edu/ jaltig/Langmuir.pdf

Annadurai G., Juang R.S. and Lee D.J. (2003), Adsorption of heavy metals from water using banana and orange peels, Water Sci. \& Technol., 47(1), 185-190.

Anto S.M. and Annadurari G. (2012), Arsenic Adsorption from Aqueous Solution Using Chistosan Nanoparticle, Res. J. Nanosci. and Nanotechnol., 2(2), 31-45.

APHA (2005), Standard Methods for the Examination of Water and Wastewater. 21st ed., American public health association, Washington DC.

Aziz S.Q. (2012), Landfill leachate treatment using powdered activated carbon augmented sequencing batch reactor (SBR) process. PhD thesis, School of Civil Engineering, Universiti Sains Malaysia, Malaysia.

Aziz S.Q., Aziz H.A., Yusoff M.S. and Bashir M.J.K. (2011), Landfill leachate treatment using powdered activated carbon augmented sequencing batch reactor (SBR) process: optimization by response surface methodology, Journal of Hazardous Materials, 189, 404-413.
Aziz S.Q., Aziz H.A., Yusoff M.S., Mojiri A. and Amr S.S.A. (2012), Adsorption isotherms in landfill leachate treatment using powdered activated carbon augmented sequencing batch reactor technique: Statistical analysis by response surface methodology, Inter. J. Chem. Reactor Eng., 10(1).

Aziz H.A., Yusoff M.S., Adlan M.N., Adnan N.H. and Alias S. (2004), Physico-chemical removal of iron from semi-aerobic landfill leachate by limestone filter, Waste Management, 24, 353-358.

Barkhordar B. and Ghiasseddin M. (2004), Comparision of Langmuir and Freundlich Equilibriums in $\mathrm{Cr}, \mathrm{Cu}$ and $\mathrm{Ni}$ Adsorption by Sargassum Iran, J Environ Health Sci. Eng., 1, 58-64.

Bhattacharyya K.G. and Gupta S.S. (2008), Kaolinite and montmorillonite as adsorbents for Fe (III), $\mathrm{Co}(\mathrm{II})$ and $\mathrm{Ni}$ (II) in aqueous medium, Applied Clay Science, 41, 1-9.

Coates J. (2000), Interpretation of Infrared Spectra, A Practical Approach. John Wiley \& Sons Ltd, Chichester, pp. 1081510837.

Dada A.O., Olalekan A.P., Olatunya A.M. and Dada O. (2012), Langmuir, Freundlich, Temkin and Dubinin-Radushkevich Isotherms Studies of Equilibrium Sorption of $\mathrm{Zn}^{2+}$ Unto Phosphoric Acid Modified Rice Husk, IOSR J. App. Chem., 3(1), 38-45.

de Castro Sousa J.F. (2009), Combination of electrochemical and ion-exchange methods in metal separation. MSc Thesis, Universidade do Porto.

Dodbiba G, Wu IC, Lee Y.C., Matsuo S. and Fujita T. (2010), Adsorption of Molybdenum Ion in Nitric Acid Solution by Using a Pb-Fe Based Adsorbent, Int. J. Soc. Mater. Eng. Resour., 17(1), 28-34.

Egute N.D.S., Sousa J.S. and Yamaura M. (2011), Study on removal of molybdenum from aqueous solution using sugarcane bagasse ash as adsorbent. 2011 International Nuclear Atlantic Conference - INAC, Belo Horizonte, MG, Brazil, October 2428.

Fujita T., Dodbiba G., Sadaki J. and Shibayama A. (2006), Removal of Anionic Metal lons from Wastewater by Hydroxide-type Adsorbents, The Chinese J. Process Eng., 3(6), 357-362.

Galindo L.S.G., de Almeida Neto A.F., da Silva M.G.C. and Vieira M.G.A. (2013), Removal of Cadmium(II) and Lead(II) ions from aqueous phase on sodic bentonite. Materials Research, 6(2), 515-527.

Gatsios E., Hahladakis J.N. and Gidarakos E. (2015), Optimization of electrocoagulation (EC) process for purification of a real industrial wastewater from toxic metals, Journal of Environmental management, 154, 117-127

Hamdaoui O. and Naffrechoux E. (2007), Modeling of adsorption isotherms of phenol and chlorophenols onto granular activated carbon Part I. Two-parameter models and equations allowing determination of thermodynamic parameters, Journal of Hazardous Materials, 147, 381-394.

Isa M.H., Lang L.S., Assari F.A.H. Aziz, H.A., Ramli N.A. and Dhas J.P.A. (2007), Low cost removal of disperse dyes from aqueous solution using palm ash, Dyes and Pigments, 74, 446-453.

Kafshgari F., Keshtkar F. and Mousavian M.A. (2013), Study of Mo (VI) removal from aqueous solution: application of different mathematical models to continuous biosorption data, Iranian J. Environ. Health Sci. \& Eng., 10, 14.

Kamba A.S., Ismail M., Ibrahim T.A.T. and Zakaria Z.A.B. (2013), Synthesis and Characterisation of Calcium Carbonate 
Aragonite Nanocrystals from Cockle Shell Powder (Anadara granosa), Journal of Nanomaterials, 8, Article ID 398357.

Kohler S.J., Cubillas P., Rodriguez-Blanco J.D., Bauer C. and Prieto M. (2008), Removal of Cadmium from Wastewaters by Aragonite Shells and the Influence of Other Divalent Cations, Environ. Sci. Technol., 41, 112-118.

Krika F. and Benlahbib O.F. (2015), Removal of methyl orange from aqueous solution via adsorption on cork as a natural and low-coast adsorbent: equilibrium, kinetic and thermodynamic study of removal process, Desalination and Water Treatment, 53, 3711-3723.

Lian J., Xu S., Yu C. and Han C. (2012), Removal of Mo(VI) from aqueous solutions using sulfuric acid-modified cinder: kinetic and thermodynamic studies, Toxicological \& Environmental Chemistry, 94(3), 500-511.

Liao W.P, Yang R., Kuo W.T. and Huang J.Y. (2014), The application of electrocoagulation for the conversion MSWI fly ash into nonhazardous materials, Journal of Environmental Management, 137, 157-162.

Meena A.K., Mishra G.K., Rai P.K., Rajagopal C. and Nagar P.N. (2005), Removal of heavy metal ions from aqueous solutions using carbon aerogel as an adsorbent, Journal of Hazardous Materials, 122(1-2), 161-170.

Meena A.K., Rajagopal C., Kiran, and Mishra G.K. (2010), Removal of heavy metals ions from aqueous solutions usin chemically $\left(\mathrm{Na}_{2} \mathrm{~S}\right)$ treated granular activated carbon as an adsorbent, $J$. Scientific \& Industrial Research, 69, 449-453.

Mehdizadeh S., Sadjadi S., Ahmadi S.J. and Outokesh M. (2014), Removal of heavy metals from aqueous solution using platinum nanopartcles/Zeolite-4A, Journal of Environmental Health Science and Engineering, 12, 7.

Mohajeri S., Aziz H.A., Isa M.H., Zahed M.A. and Adlan M.N. (2010), Statistical optimization of process parameters for landfill leachate treatment using electro-Fenton technique, Journal of Hazardous Materials, 176, 749-758.

Moideen S.N.F., Din M.F.M., Ponraj M., Yusof M.B.M., Ismail Z., Songip A.R. and Chelliapan S. (2015), Wasted cockle shell (Anadara granosa) as a natural adsorbent for treating polluted river water in the fabricated column model (FCM). Desalination and Water Treatment, 57(35), 16395-16403.

Mojiri A. (2011), Review on Membrane Bioreactor, Ion Exchange and adsorption Methods for Landfill Leachate Treatment. Australian Journal of Basic and Applied Sciences, 5(12), 13651370.

Mojiri A., Aziz H.A., Zaman N.Q., Aziz S.Q. and Zahed M.A. (2014), Powdered ZELIAC augmented sequencing batch reactors (SBR) process for co-treatment of landfill leachate and domestic wastewater, Journal of Environmental Management, 139, 1-14.

Mojiri A., Aziz H.A., Zaman N.Q. Aziz S.Q. and Zahed M.A. (2016), Metals Removal from Municipal Landfill Leachate and Wastewater Using Adsorbents Combined with Biological Method, Desalination and Water Treatment, 57(6), 28192833.

Mojiri A., Aziz H.A., Zahed M., Aziz S.Q. and Selamat M.R.B. (2013), Phytoremediation of heavy metals from urban waste leachate by Southern Cattail (Typha domingensis), Inter. J. Sci. Res. Environ. Sci., 1(4), 63-70

Moret A. and Rubio J. (2003), Sulphate and molybdate ions uptake by chitin-based shrimp shells, Minerals Eng., 16, 715-22.
Namasivayam C. and Sureshkumar M.V. (2009), Removal and Recovery of Molybdenum from Aqueous Solutions by Adsorption onto Surfactant- Modified Coir Pith, a Lignocellulosic Polymer, CLEAN - Soil, Air, Water, 37(1), 60-66.

Naswir M., Arita S., Marsi, and Salni S. (2013), Characterization of Bentonite by XRD and SEM-EDS and Use to Increase PH and Color Removal, Fe and Organic Substances in Peat Water, Journal of Clean Energy Technology, 1(4), 313-317.

Nishihama S. and Yoshizuka K. (2009), lon Exchange Adsorption of Molybdenum with Zeolitic Adsorbent, J. Environ. Eng. Manage., 19(6), 365-369.

Olaniran A.O., Balgobind A., and Pillay B. (2013), Bioavailability of Heavy Metals in Soil: Impact on Microbial Biodegradation of Organic Compounds and Possible Improvement Strategies, Int. J. Mol. Sci., 14(5), 10197-10228

Pagnanelli F., Ferella F., De Michelis I. and Vegliò F. (2011), Adsorption onto activated carbon for molybdenum recovery from leach liquors of exhausted hydrotreating catalysts, Hydrometallurgy, 110(4), 1-4.

Rabelo M.S., Colodette J.L., Sacon V.M., Silva M.R. and Azevedo M.A.B. (2008), Molybdenum Catalyzed Acid Peroxide Bleaching of Cucalyptus Kraft Pulp, BioResources, 3(3), 881-879.

Ragheb S.M. (2013), Phosphate removal from aqueous solution using slag and fly ash, HBRC Journal, 9, 270-275.

Sajidu S.M.I., Persson I., Masamba W.R.L. and Henry E.M.T. (2008), Mechanisms of heavy metal sorption on alkaline clays from Tundulu in Malawi as determined by EXAFS, Journal of Hazardous Materials, 158, 401-409.

Umar M., Aziz H.A. and Yusoff M.S. (2011), Assessing the chlorine disinfection of landfill leachate and optimization by response surface methodology (RSM), Desalination, 274(1-3), 278-283.

Vlachou M., Hahladakis J. and Gidarakos E. (2013), Effect of Various Parameters in Removing $\mathrm{Cr}$ and $\mathrm{Ni}$ from Model Wastewater by Using Electrocoagulation, Global NEST Journal, 15(4), 494-503.

Yamada K., Haraguchi K., Gacho C.C., Salinas L.S., Silverio C.M. and Wongsiri B.P. (2001), Removal of phosphate from aqueous solution by crystallization using coal fly ash, International Ash Utilization Symposium, Center for Applied Energy Research, University of Kentucky, USA.

Yu C., Xu S., Gang M., Chen G. and Zhou L. (2011), Molybdenum pollution and speciation in Nver River sediments impacted with Mo mining activities in western Liaoning, northeast China., Inter. J. Environ. Res., 5, 205-12. 